\title{
Effects of Callianassa kraussi on microbial biofilms and recruitment of macrofauna: a novel hypothesis for adult-juvenile interactions
}

\author{
D. Pillay ${ }^{1, *}$, G. M. Branch ${ }^{2}$, A. T. Forbes ${ }^{1}$ \\ ${ }^{1}$ School of Biological and Conservation Sciences, University of KwaZulu-Natal, Durban 4041, South Africa \\ ${ }^{2}$ Marine Biology Research Institute, Zoology Department, University of Cape Town, PB X3, Rondebosch 7701, South Africa
}

ABSTRACT: The reworking of sediments by callianassid sandprawns has important effects on the adults of softbottom macrofaunal communities; however, its influence on juvenile stages has been neglected, even though this may dictate the composition of adult assemblages. We examined the effects of the southern African sandprawn Callianassa kraussi to test the hypotheses that (1) C. kraussi negatively affects juvenile recruitment and inhibits microbial biofilms on the sediment, and (2) depletion of microbial biofilms will in itself diminish juvenile recruitment. Comparisons between areas of high and low C. kraussi density in addition to field caging experiments demonstrated a significant retardation of biofilm development and recruitment of juvenile macrofauna by C. kraussi. Juvenile assemblages in sediments where $C$. kraussi was absent or rare differed significantly from those in which $C$. kraussi was abundant, with greater densities of suspension- and subsurface-feeding polychaetes and bivalves in cases where C. kraussi was rare or absent. Total abundance, taxonomic richness and diversity of juveniles were also significantly greater in cases where C. kraussi was rare. Experimental manipulation of sediment microbial films showed that biofilmed sediments had significantly different assemblages from unfilmed ones, with abundance, richness and diversity of recruits being significantly greater in biofilmed sediments. The effect of C. kraussi on juveniles of the macrofauna, apparently brought about via its effects on biofilms, emerges as one of the primary mechanisms structuring macrofaunal communities. The effects of sandprawns on juvenile stages must be considered if we are to understand the role of sandprawns in structuring soft-sediment assemblages.

KEY WORDS: Callianassa - Bioturbation · Juvenile · Recruitment $\cdot$ Microbial biofilm

Resale or republication not permitted without written consent of the publisher

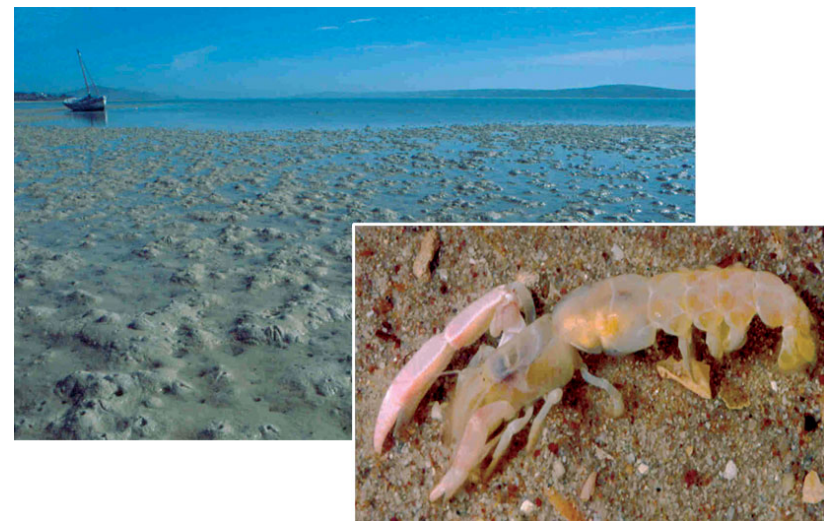

Uneven sediment topography on a tidal flat with mounds created by Callianassa kraussi (inset).

Photos: G. M. Branch (tidal flat) \& Charles Griffiths (inset)

\section{INTRODUCTION}

Interactions among adult invertebrates, such as predation and competition, have been recognised as key processes responsible for structuring marine assemblages (e.g. Branch 1984). However, interactions between adults and juveniles have also emerged as key structuring agents (Osman \& Whitlatch 1995, Eckman 1996). The effects of bioturbation have been a focal point in soft-substrate environments, where adult-adult (eg. Brenchley 1981, Posey et al. 1991, Widdicombe et al. 2000) and adult-juvenile (Woodin 1976, Woodin et al. 1998) interactions have also been shown to significantly influence communities. Particular attention has been paid to callianassid sandprawns because they transform sediments to such an extent 
that they have been cited as 'ecosystem engineers', but interactions among adult stages have dominated such research (Branch \& Pringle 1987, Berkenbusch et al. 2000, Berkenbusch \& Rowden 2003, Siebert \& Branch 2005, 2006).

Consequently, current views concerning the mechanisms by which sandprawns influence invertebrate communities centre around adult-adult interactions, while their effects on the recruitment of juvenile stages of macrofauna have been neglected, despite demonstrations that the recruitment of juvenile invertebrates is significantly influenced by established residents in both rocky and soft-bottom habitats (Osman \& Whitlatch 1995, Olivier et al. 1996).

Callianassid sandprawns create deep burrows extending over $1 \mathrm{~m}$ into the sediment and bring sediment to the surface, where they deposit it in volcano-like mounds (Rowden \& Jones 1993). These burrowing activities modify sediment biogeochemical properties, particularly pore-water, nutrient and gaseous interchange between the sediment and water column (Waslenchuk et al. 1983, Murphy \& Kremer 1992) and sediment granulometry and erodibility (Flach \& Tamaki 2001). Adult sandprawns therefore have the potential to influence the settlement and recruitment of other species because their burrowing activities influence sediment characteristics. In addition, by expelling sediments from their burrows to the sediment surface, sandprawns may diminish microbial biofilms there.

Biofilms are essentially a mix of bacteria and diatoms embedded in a matrix of extracellular polymeric substances (EPSs) exuded by these organisms (Underwood \& Paterson 1995, Gu et al. 1998). They play key roles in marine ecosystems by (1) binding the topmost sediment layer and promoting laminar flow of water over the sediment bed (Paterson \& Hagerthey 2001), (2) serving as food sources for adult and larval invertebrates (Decho \& Lopez 1993), and (3) providing cues for the settlement of invertebrate larvae $(\mathrm{Gu}$ et al. 1998, Huang \& Hadfield 2003).

Although some research indicates a negative influence of biofilms on the settlement of invertebrate larvae (Wieczorek \& Todd 1998, Lau et al. 2003, Dobretsov \& Qian 2006), most evidence indicates that they promote larval settlement (Gu et al. 1988, Hadfield \& Paul 2001, Huang \& Hadfield 2003).

In the present study, we observationally and experimentally examined the effects of bioturbation by the southern African sandprawn Callianassa kraussi on sediment microbial biofilms and recruitment of juvenile macrofauna. To test our hypotheses, we firstly employed field observations in which biofilms and juvenile assemblages were compared between areas that naturally have high and low C. kraussi density. We then utilised field inclusion/exclusion cages to experi- mentally assess the effects of $C$. kraussi on biofilms and on the recruitment of juvenile macrofauna. Finally, biofilms were experimentally manipulated to test the consequences for juvenile recruitment.

\section{MATERIALS AND METHODS}

Study site. The research was undertaken in Durban Bay on the east coast of South Africa either at a

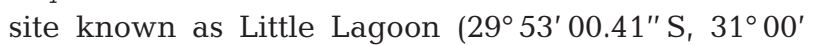
$34.43^{\prime \prime} \mathrm{E}$ ) or at the Natal Sharks Board (NSB) base $1.5 \mathrm{~km}$ to the south $\left(29^{\circ} 53^{\prime} 53.20^{\prime \prime} \mathrm{S}, 31^{\circ} 00^{\prime} 20.77^{\prime \prime} \mathrm{E}\right)$. Little Lagoon is flanked to the north and south by sandbanks, some areas of which are occupied by dense populations of the sandprawn Callianassa kraussi $\left(130 \pm 17.5 \mathrm{~m}^{-2}\right)$, whereas other areas either lack or have very low densities of this prawn $\left(2.7 \pm 2.5 \mathrm{~m}^{-2}\right)$.

Field observations. Field observations, in which microbial biofilms and recruitment were compared between adjacent areas of high and low Callianassa kraussi density, were used as a prelude to our field experiments. The unequal sizes of the high- and lowdensity patches of $C$. kraussi dictated an unbalanced sampling design, with 4 sites sampled in areas with high C. kraussi density (H1 to H4) and 2 sites sampled in the low-density area (L1 and L2), distributed over both the northern and southern sandbanks. In both high- and low-density areas, physico-chemical variables and $C$. kraussi abundance were measured, and samples of bacterial abundance, EPS concentrations, microphytobenthic biomass and juvenile macrofauna were taken during March and August 2004.

Physico-chemical variables: To test whether differences in physico-chemical properties between the areas of high and low density might confound the effects of Callianassa kraussi on biofilms and recruitment, measurements were made of water temperature and salinity (measured using a mercury thermometer and an optical refractometer), sediment particle sizes and organic content (determined according to Morgans 1956) during mid-high spring tides.

Effects of Callianassa kraussi on recruitment and biofilms: Biofilm properties: For microphytobenthos, cores $(\mathrm{n}=3$ per site, diameter $=2 \mathrm{~cm}$, length $=1 \mathrm{~cm}$ ) were collected and refrigerated in $30 \mathrm{ml}$ of $90 \%$ acetone for $24 \mathrm{~h}$ to extract chl a. Fluorescence was measured using a Turner Designs 10-AU fluorometer fitted with a narrow band, non-acidification system. Additional cores $(\mathrm{n}=3$, diameter $=2 \mathrm{~cm}$, length $=0.5 \mathrm{~cm}$ ) were collected to determine sediment microbial EPS levels, which were measured using the phenol-sulfuric acid assay (Underwood \& Paterson 1995). In brief, $2 \mathrm{ml}$ of distilled water was added to pre-weighed sediment, followed by additions of $5 \%$ aqueous phenol (wt/vol) 
and $5 \mathrm{ml}$ concentrated hydrochloric acid. The absorbance was measured against a reagent blank at $485 \mathrm{~nm}$ using a spectrophotometer. Calibration was performed using a standard curve of absorbance against glucose concentrations. To quantify bacterial abundance, further sediment cores $(\mathrm{n}=3$ per site, diameter $=2 \mathrm{~cm}$, length $=0.5 \mathrm{~cm}$ ) were collected at each sampling site, fixed with $2 \mathrm{ml}$ of $4 \%$ formaldehyde, then sonicated for 2 min and stained with $2 \mathrm{ml}$ acridine-orange for $5 \mathrm{~min}$. A $25 \mu \mathrm{l}$ liquid-fraction sample was withdrawn and viewed using epifluorescence microscopy. Bacterial cells from 20 fields of view were counted per replicate.

Juvenile macrofauna: Sediment cores ( $\mathrm{n}=9$ per site, diameter $=10 \mathrm{~cm}$, length $=20 \mathrm{~cm}$ ) were preserved with $4 \%$ formaldehyde, stained with Phloxine-B, and sieved through a $500 \mu \mathrm{m}$ mesh to remove adult macrofauna. Material that passed through this sieve was then sieved through a $63 \mu \mathrm{m}$ mesh and viewed under a dissecting microscope to identify and count juvenile macrofauna.

Callianassa kraussi density: Numbers of burrow openings were used as indicators of C. kraussi abundance and bioturbation, as previous studies have shown a 1:1 ratio of holes to prawns (Forbes 1973). Twenty replicate hole counts were made per site by counting the number of $C$. kraussi holes per quadrat $\left(30 \times 40 \mathrm{~cm}\right.$, area $\left.=0.12 \mathrm{~m}^{-2}\right)$, and then extrapolating to number of burrow holes $\mathrm{m}^{-2}$.

Field experiments. Effects of Callianassa kraussi on recruitment and biofilms: An exclusion/inclusion experiment was conducted in the intertidal zone of Little Lagoon in an area with low C. kraussi density. Three treatments were employed: (1) cages that included C. kraussi, (2) cages excluding C. kraussi and (3) a method control. Ten unroofed rectangular cages $(50 \times 50 \times 30 \mathrm{~cm}$ deep) covered with $1 \mathrm{~mm}$ mesh were sunk into the sediment, filled with sun-dried defaunated sediment and left standing for $2 \mathrm{~d}$. Sandprawns ( $\mathrm{n}=30$ per cage; 5 to $7 \mathrm{~cm}$ total length) were then introduced to 5 cages (inclusion treatment), and the remaining 5 cages were left empty (exclusion treatment). Treatments were systemically interspersed. Two prawns were added to each inclusion cage every month to compensate for any mortality that might have occurred. The method control was instituted to assess possible caging effects and comprised samples taken from an adjacent uncaged area where the density of $C$. kraussi was equivalent to that in the inclusion cages. The rationale was that if control and inclusion treatments yielded comparable results, then cage artifacts were unlikely (Posey et al. 1991, Reinsel 2004).

Sampling started 3 mo after installation of the cages, and took place in March, June and September 2005. On each occasion, 3 samples were collected per cage, totalling 15 per treatment, together with 15 random control samples. The positions of samples collected from cages were recorded to avoid resampling the same area on successive dates, so that samples were temporally independent.

Juvenile macrofauna, microphytobenthic biomass and EPS concentrations were sampled and analysed as above. EPS concentration was used as in indication of bacterial abundance in this aspect of our investigation as data from our field observations indicated a tight correlation between the two $(\mathrm{r}=0.914, \mathrm{n}=36, \mathrm{p}<$ 0.0001; Pillay 2006).

Effects of biofilms on juvenile recruitment: To determine the effects of sediment microbial biofilms on juvenile recruitment, sediments with well-developed and poorly developed microbial biofilms were experimentally developed under laboratory conditions, transferred to the intertidal sediments near the NSB base, and juvenile assemblages developing on them compared between the treatments.

Production of biofilmed and non-biofilmed sediments: Intertidal sediment was collected from Durban Bay and autoclaved to destroy all life. Seawater collected from the bay was sieved through Whatman GFF filter paper to remove any larvae while allowing bacteria to pass through. Half the sediment was then placed in 12 trays $(30 \times 20 \times 10 \mathrm{~cm}$ deep), to which the filtered seawater was added to cover the sediment to a depth of 1 to $2 \mathrm{~mm}$; this treatment was termed the +biofilm treatment. For the-biofilm treatment, filtered seawater that had been autoclaved to kill microbiota was added to another set of 12 trays containing autoclaved sediments; UV lights (UV-B, wavelength $=285 \mathrm{~nm}$ ) were positioned above these trays to inhibit any microbiota that may have survived the autoclaving process (Lau et al. 2003). Both treatments stood in the laboratory for $1 \mathrm{mo}$ and were then installed in the intertidal zone in front of the NSB base by sinking the trays flush with the sediment surface, with systemic interspersion of treatments.

Sampling strategy: Six trays of each treatment were removed after $3 \mathrm{~d}$ and the remaining six after $7 \mathrm{~d}$. Three replicate sediment cores (diameter $=2 \mathrm{~cm}$, length $=1 \mathrm{~cm}$ ) were collected from each tray $1 \mathrm{~d}$ before installing the trays in the field (Day 0), as well as $3 \mathrm{~d}$ (Day 3) or $7 \mathrm{~d}$ (Day 7) after their deployment in the field, and processed as above to measure chl a. Three replicate sediment cores (diameter $=2 \mathrm{~cm}$, length $=$ $0.5 \mathrm{~cm}$ ) were collected at corresponding times, and processed as above to measure EPS. The remaining sediment in each tray was processed as above to quantify recruits after Days 3 and 7.

Statistical analyses. PRIMER v. 5 was used to apply non-metric multidimensional scaling (MDS) to compare juvenile assemblages between treatments using untransformed and unstandardised abundance data. Analysis of similarity (ANOSIM) statistically tested if 
juvenile assemblages differed between treatments. Correlations were performed between juvenile assemblages and physico-chemical parameters, biofilm properties and abundance of Callianassa kraussi using the BIO-ENV routine to determine causal relations between these variables obtained from our field observations. The DIVERSE procedure was used to calculate the following community parameters for each treatment: total abundance $(N)$, taxonomic richness (expressed as total number of taxa, $S$ ), and ShannonWiener diversity $\left(H^{\prime}\right)$ to the base e. SIMPER identified juvenile taxa that characterised and distinguished treatments. ANOVA and post-hoc Tukey tests were employed to assess differences in biofilm properties and juvenile community parameters among treatments. Student $t$-tests tested for differences in physico-chemical variables for each season; the significance level for these tests was set at 0.1 due to the low sample sizes ( $\mathrm{n}=2$ for sites of low C. kraussi density for each season).

A 2-way ANOVA was used to determine if biofilm parameters differed between sites of high and low Callianassa kraussi densities, with time and site as fixed factors. Assumptions of data normality and homogeneity of variance were assessed using the Kolmogorov-Smirnov and Levene's tests, respectively. When necessary, the data were transformed $(\log +1$ or arcsin) to meet these assumptions. In some instances, transformations did not result in data normality or homogeneity of variance. In these cases, non-parametric tests were applied.

\section{RESULTS}

\section{Physico-chemical variables}

There were no significant differences between any of the physico-chemical variables between the sites of high and low Callianassa kraussi density during either sampling season (Table 1 ; $t$-tests $\mathrm{p}>0.1$ for both March and August for all variables).

Table 1. Temperature, salinity, sediment organic content and sediment median particle size (mean $\pm \mathrm{SE}$ ) in areas of high and low Callianassa kraussi densities

\begin{tabular}{|lcccc|}
\hline Area & $\begin{array}{c}\text { Temp. } \\
\left({ }^{\circ} \mathrm{C}\right)\end{array}$ & $\begin{array}{c}\text { Salinity } \\
(\%)\end{array}$ & $\begin{array}{c}\text { Sediment } \\
\text { organic } \\
\text { content }(\%)\end{array}$ & $\begin{array}{c}\text { Sediment } \\
\text { particle size } \\
(\phi \text { units })\end{array}$ \\
\hline $\begin{array}{l}\text { March } \\
\text { High }\end{array}$ & $26.6 \pm 0.6$ & $34 \pm 0.25$ & $3.25 \pm 0.19$ & $1.98 \pm 0.04$ \\
Low & $26.0 \pm 1.0$ & $34 \pm 0.01$ & $3.35 \pm 0.25$ & $2.10 \pm 0.10$ \\
August & & & & \\
High & $21.2 \pm 0.41$ & $32 \pm 0.28$ & $2.85 \pm 0.13$ & $2.15 \pm 0.06$ \\
Low & $20.5 \pm 0.1$ & $33.5 \pm 0.5$ & $2.75 \pm 0.25$ & $2.35 \pm 0.05$ \\
\hline
\end{tabular}

\section{Biofilm properties}

From the field observations, densities of bacteria, benthic microalgae and concentrations of EPS were significantly greater at sites with low Callianassa kraussi densities than at high-density sites (Fig. 1; p < 0.0001 in all cases). Seasonal effects and interactions between site and season were also significant $(p<0.01$ in all cases). Post-hoc analyses indicated that values for all 3 variables were significantly greater at low-density sites during both sampling seasons ( $\mathrm{p}<0.01)$.

In the manipulative field experiment (Fig. 2) concentrations of benthic microalgae and EPS differed signif-
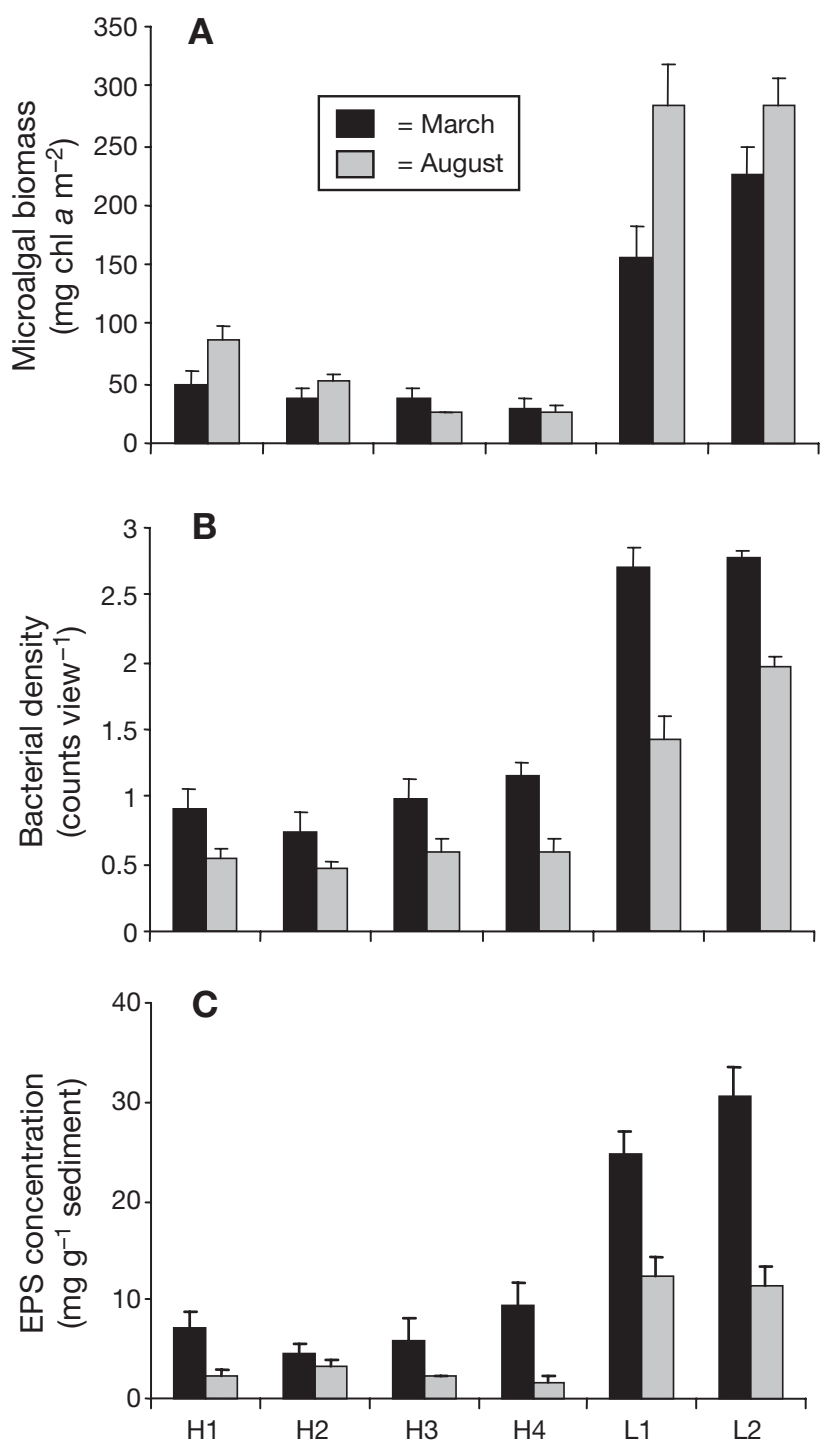

Fig. 1. Differences in (A) microalgal biomass, (B) bacterial density and (C) extracellular polymeric substance (EPS) concentrations between sites of high (H1 to H4) and low (L1 and L2) Callianassa kraussi abundance in March and August. Data are means $+1 \mathrm{SE} ; \mathrm{n}=3$ 

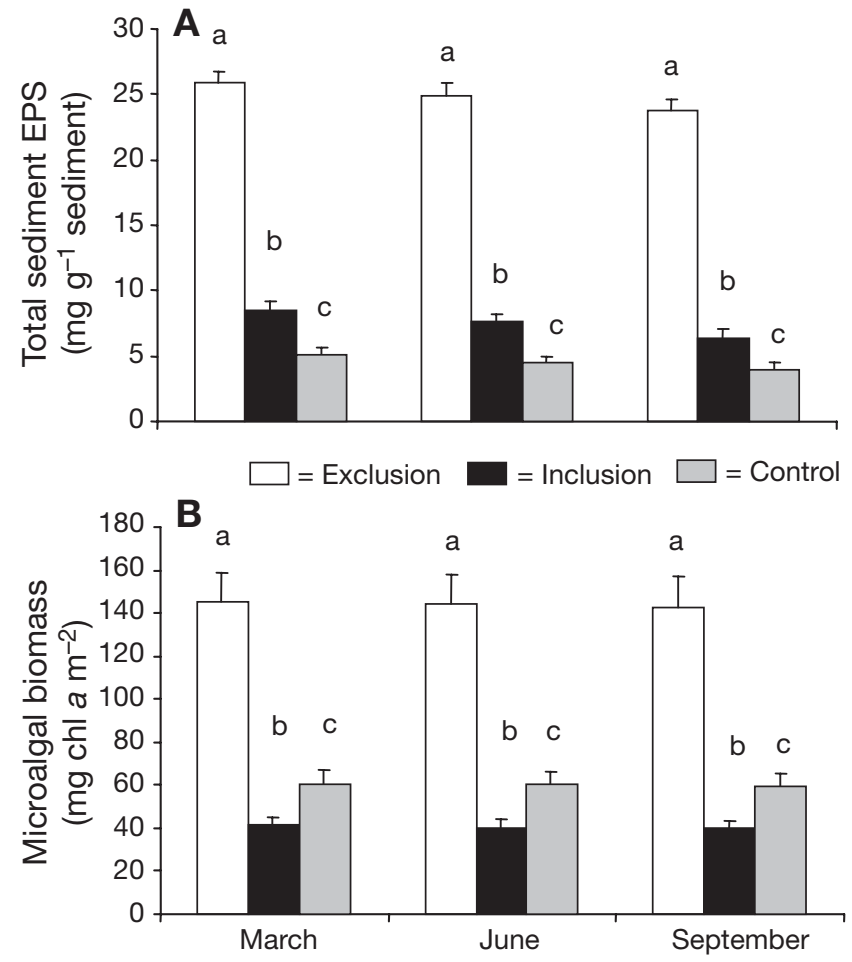

Fig. 2. Results (mean $+1 \mathrm{SE}$ ) from the field experiment showing differences in (A) total sediment EPS concentrations and (B) microalgal biomass among exclusion, inclusion and control treatments in March, June and September. Different letters indicate statistical differences between treatments within any given month $(\mathrm{p}<0.05) ; \mathrm{n}=3$

icantly among treatments $(\mathrm{p}<0.0001)$. Seasonal differences in microalgal concentration were significant $(\mathrm{p}=$ 0.008), but not for EPS levels ( $p=0.93$ ). Interactions between treatment and season were non-significant ( $p>0.5$ ). All 3 treatments were significantly different from each other on all 3 sampling seasons, but the differences between the inclusion and control were small and marginally significant, compared to the 3 - to 4 -fold greater values in the exclusion than in the inclusion treatment.

\section{Juvenile recruitment}

MDS ordinations indicated that juvenile assemblages associated with the areas of high and low Callianassa kraussi abundance were statistically different during both sampling seasons (Fig. 3; ANOSIM: March, $\mathrm{p}=0.012$; August, $\mathrm{p}=0.001$ ). Samples collected in March differed from those collected in August (ANOSIM, $\mathrm{p}=0.001$ ). Multivariate correlation analyses indicated that juvenile assemblages were strongly associated with biofilm variables and C. kraussi density, but weakly related to physico-chemical variables
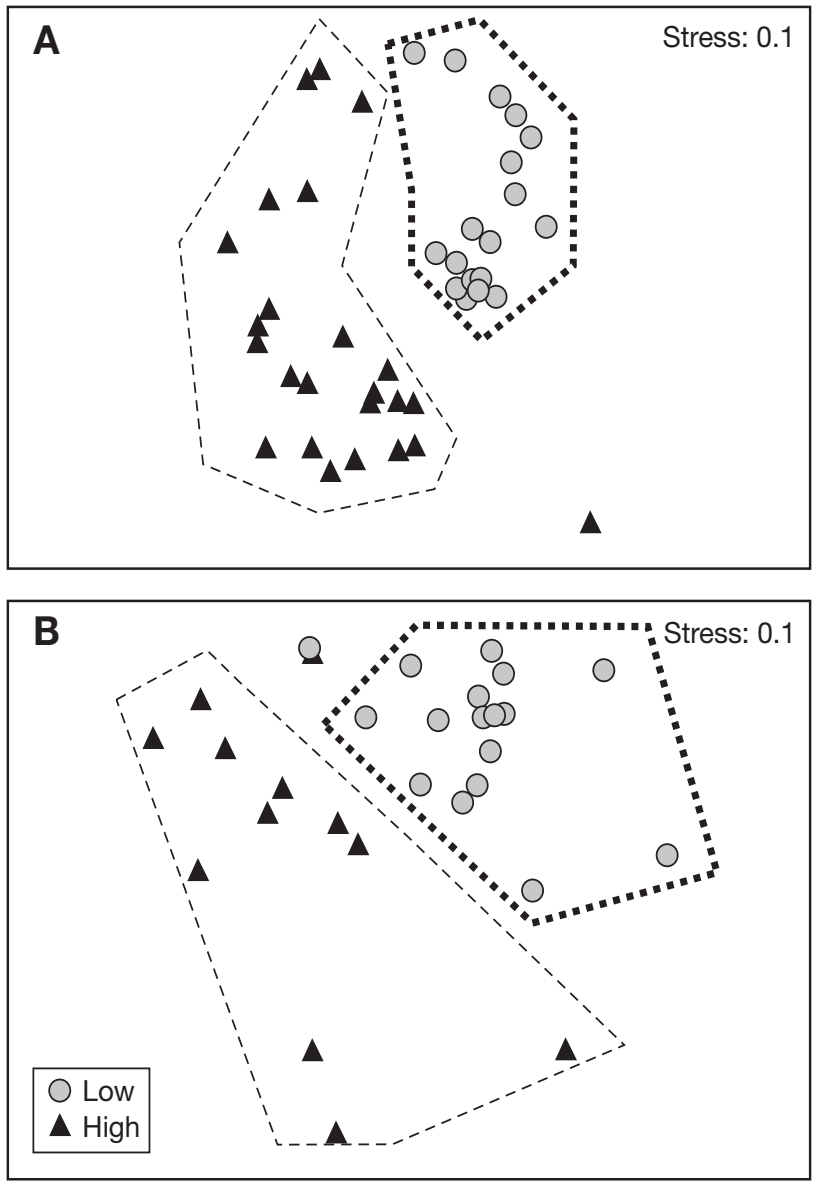

Fig. 3. Multidimensional scaling (MDS) ordinations for (A) March and (B) August, showing differences in juvenile assemblages between areas of high and low densities of Callianassa kraussi. Dashed and dotted lines unite samples that formed discrete clusters between 20 and $25 \%$ similarity. The number of data points is less than the number of samples ( $\mathrm{n}=$ 36 for high-density and $n=18$ for low-density areas) because of overlap of samples with $100 \%$ similarity

Table 2. Correlation coefficients for relationships between juvenile assemblages and physico-chemical parameters, biofilm properties and Callianassa kraussi density in March and August. Results were obtained using the BIO-ENV routine in PRIMER. EPS: extracellular polymeric substance

\begin{tabular}{|lrr|}
\hline Variable & Mar & Aug \\
\hline Physico-chemical variables & & \\
Temperature & -0.22 & -0.05 \\
Salinity & 0.19 & -0.07 \\
Sediment particle size & -0.05 & 0.36 \\
Sediment organic content & -0.28 & -0.07 \\
Biofilm properties & & \\
Sediment chl a & 0.85 & 0.68 \\
Bacteria & 0.73 & 0.87 \\
EPS & 0.77 & 0.61 \\
C. kraussi density & 0.8 & 0.7 \\
\hline
\end{tabular}



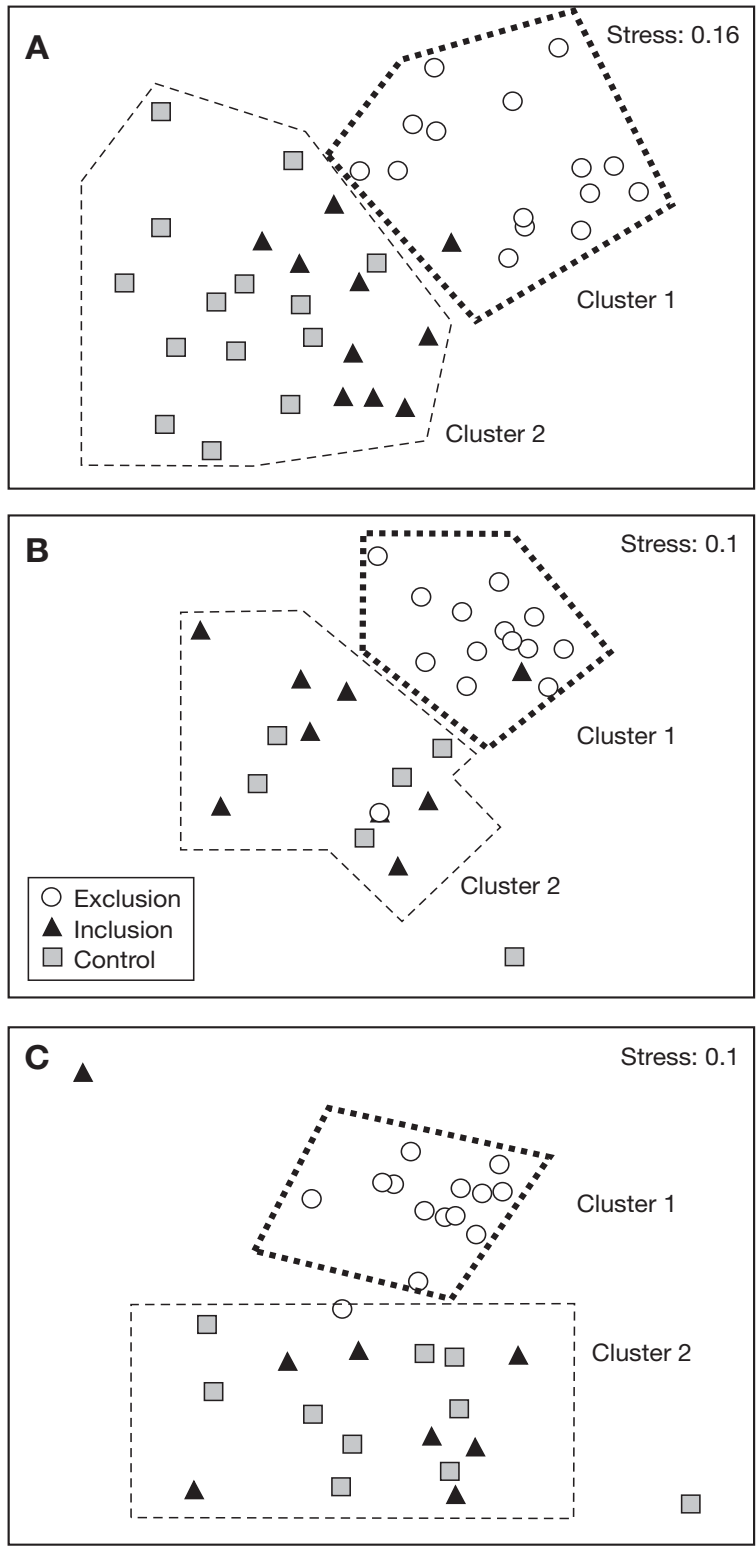

Fig. 4. MDS ordinations of juvenile assemblages between exclusion ( - C. kraussi), inclusion $(+C$. kraussi) and control treatments in (A) March, (B) June, and (C) September. The dotted and dashed lines unite samples that formed discrete clusters between 60 and $65 \%$ similarity

Table 3. Significance levels of ANOSIM and pairwise tests comparing juvenile community structure between exclusion (-C. kraussi), inclusion (+C. kraussi) and control treatments during different sampling seasons

\begin{tabular}{|lcccc|}
\hline \multirow{2}{*}{$\begin{array}{c}\text { Season } \\
\text { ANOSIM }\end{array}$} & $\begin{array}{c}\text { Global signifi- } \\
\text { Cance level }\end{array}$ & $\begin{array}{c}\text { +C. kraussi } \\
\text { vs. }- \text { C. } \text { kraussi }\end{array}$ & $\begin{array}{c}\text { Pairwise tests } \\
- \text { C. kraussi } \\
\text { vs. control }\end{array}$ & $\begin{array}{c}+ \text { +C. kraussi } \\
\text { vs. control }\end{array}$ \\
\hline Mar & 0.001 & 0.001 & 0.001 & 0.089 \\
Jun & 0.001 & 0.001 & 0.001 & 0.470 \\
Sep & 0.001 & 0.001 & 0.001 & 0.870 \\
\hline
\end{tabular}

(Table 2). Correlation coefficients between juvenile assemblages and physico-chemical variables varied between -0.07 and 0.36 , but spanned 0.61 to 0.85 for biofilm properties and C. kraussi abundance.

For the manipulative experiment, ordinations and pairwise analyses indicated that the juvenile assemblages in exclusion cages (-C. kraussi) were different from those in inclusion cages (+C. kraussi) and control plots, but the inclusion cages and control plots were never significantly different (Fig. 4, Table 3). This indicates that experimental artifacts were nonexistent or negligible but that the effects of C. kraussi were highly significant. Samples taken in March differed from those taken in June and September (pairwise tests, $\mathrm{p}<0.001)$, but the latter 2 months were not different $(\mathrm{p}>0.5)$.

Juveniles of the suspension-feeding polychaete Desdemona ornata and unidentified bivalves contributed most to the dissimilarity between assemblages in areas of high and low Callianassa kraussi abundance. Densities of these taxa were significantly greater in the areas of low C. kraussi abundance than in areas of high C. kraussi abundance in March and August (Fig. 5; p < 0.05 for both taxa in March and August; $t$-tests in March, Mann-Whitney $U$-tests in August), with up to a 100-fold greater density of $D$. ornata juveniles recorded in areas where $C$. kraussi was rare. In August, densities of juveniles of the tanaid Apseudes digitalis and of unknown crabs were clearly greater in areas where C. kraussi was rare relative to high-density sites, but these differences could not be statistically examined because the numbers of $A$. digitalis and juvenile crabs were, respectively, zero and one in the high-density treatment.

In the manipulative experiment, densities of unidentified bivalves and polychaetes were consistently significantly greater in the exclusion cages than the inclusion ones in all seasons (Fig. 6; p $<0.0001$ for both taxa for all 3 seasons). In June and August, 2 other polychaetes - Desdemona ornata $(\mathrm{p}<0.0001$ in June, no statistical tests for August as this species was then absent from the inclusion treatment) and Prionospio sexoculata $(p=0.003$ in June, $p=0.03$ in August) - were more abundant in the exclusion than inclusion cages. None of the taxa differed significantly between inclusion cages and controls during any sampling season $(\mathrm{p}>$ 0.05 in all cases), again indicating an absence of cage-induced effects.

Field observations indicated that recruit abundance (Mann-Whitney $U$-test, p < 0.0001 during both seasons), richness (Mann-Whitney $U$-test, $\mathrm{p}<0.01$ for March, $\mathrm{p}$ $<0.0001$ for August) and diversity (Mann- 


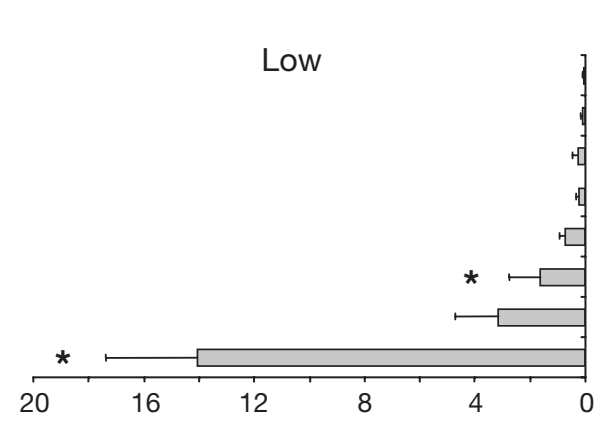

March

Glycerid polychaetes

Cumaceans

Prionospio sexoculata

Leptanthura laevigata

Unidentified polychaetes

Bivalves

Apseudes digitalis

Desdemona ornata

\section{August}

Cumaceans

Unidentified isopods

Prionospio sexoculata

Unidentified polychaetes

Bivalves

Leptanthura laevigata

Apseudes digitalis

Desdemona ornata

Crab juveniles

Taxa
High
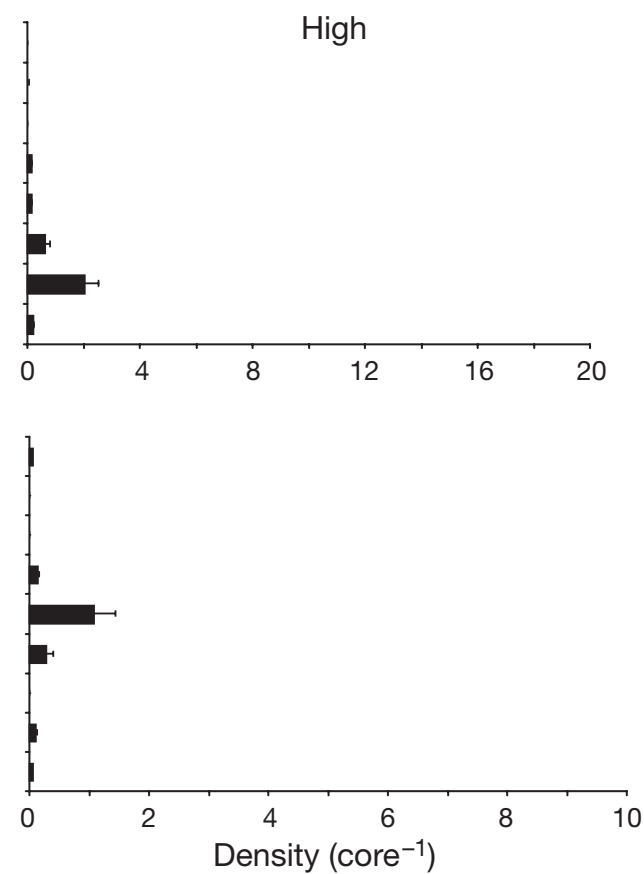

Fig. 5. Differences in abundance of juvenile taxa (mean $+1 \mathrm{SE}$ ) between areas of high and low Callianassa kraussi abundance during March and August. ${ }^{*} \mathrm{p}<0.05,{ }^{* *} \mathrm{p}<0.01 ; \mathrm{n}=9$ per site
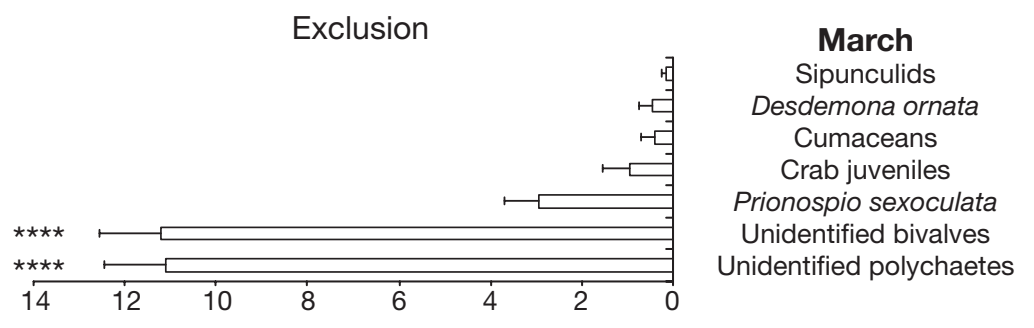

June
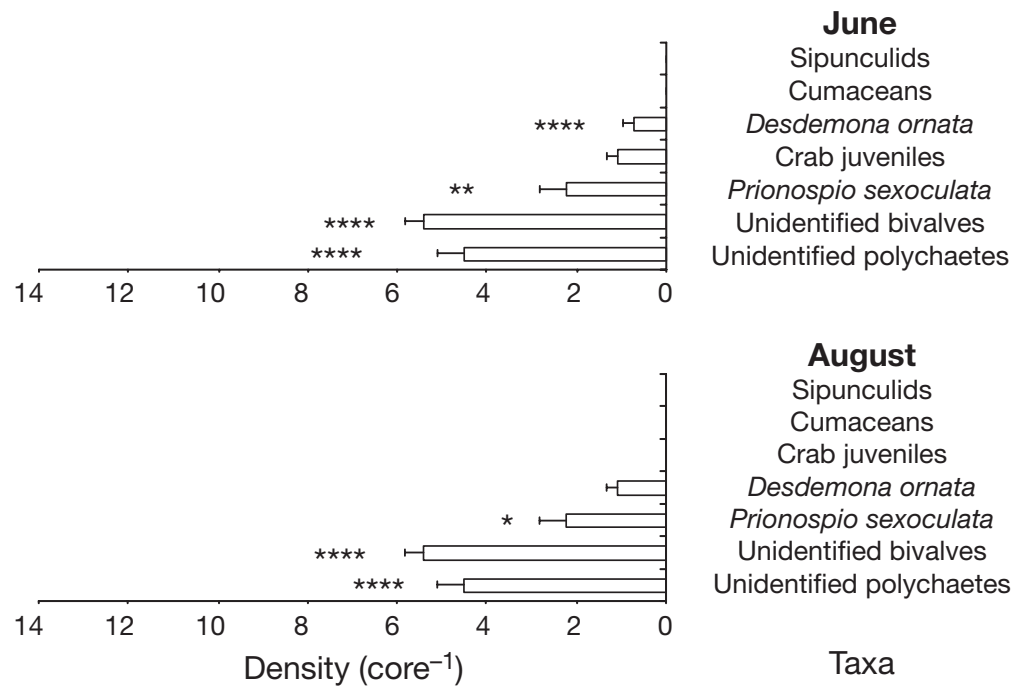

August

Sipunculids

Cumaceans

Crab juveniles

Desdemona ornata

Prionospio sexoculata

Unidentified bivalves

Unidentified polychaetes

Taxa
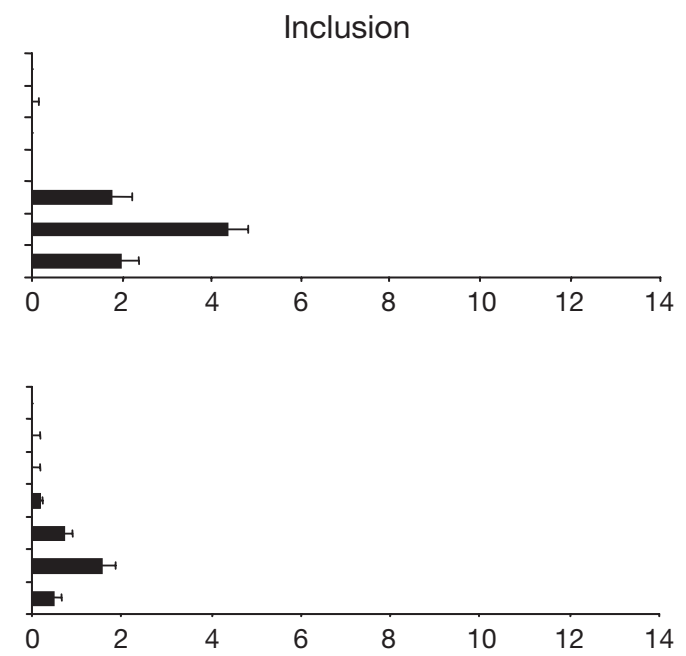

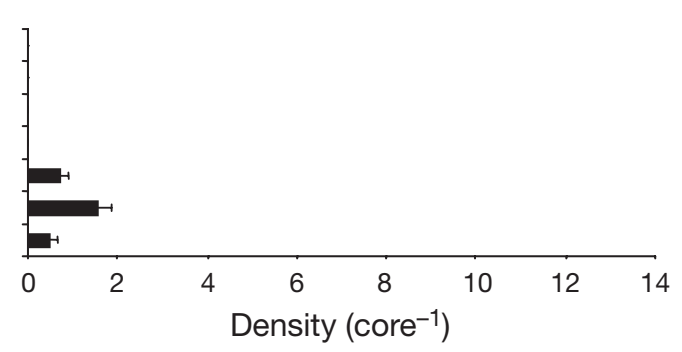

Fig. 6. Differences in abundance of juvenile macrofauna (mean $+1 \mathrm{SE}$ ) between inclusion (+C. kraussi) and exclusion (-C. kraussi) treatments during March, June and August. ${ }^{*} \mathrm{p}<0.05,{ }^{* *} \mathrm{p}<0.01,{ }^{* * * *} \mathrm{p}<0.0001 ; \mathrm{n}=15$ per treatment per season 

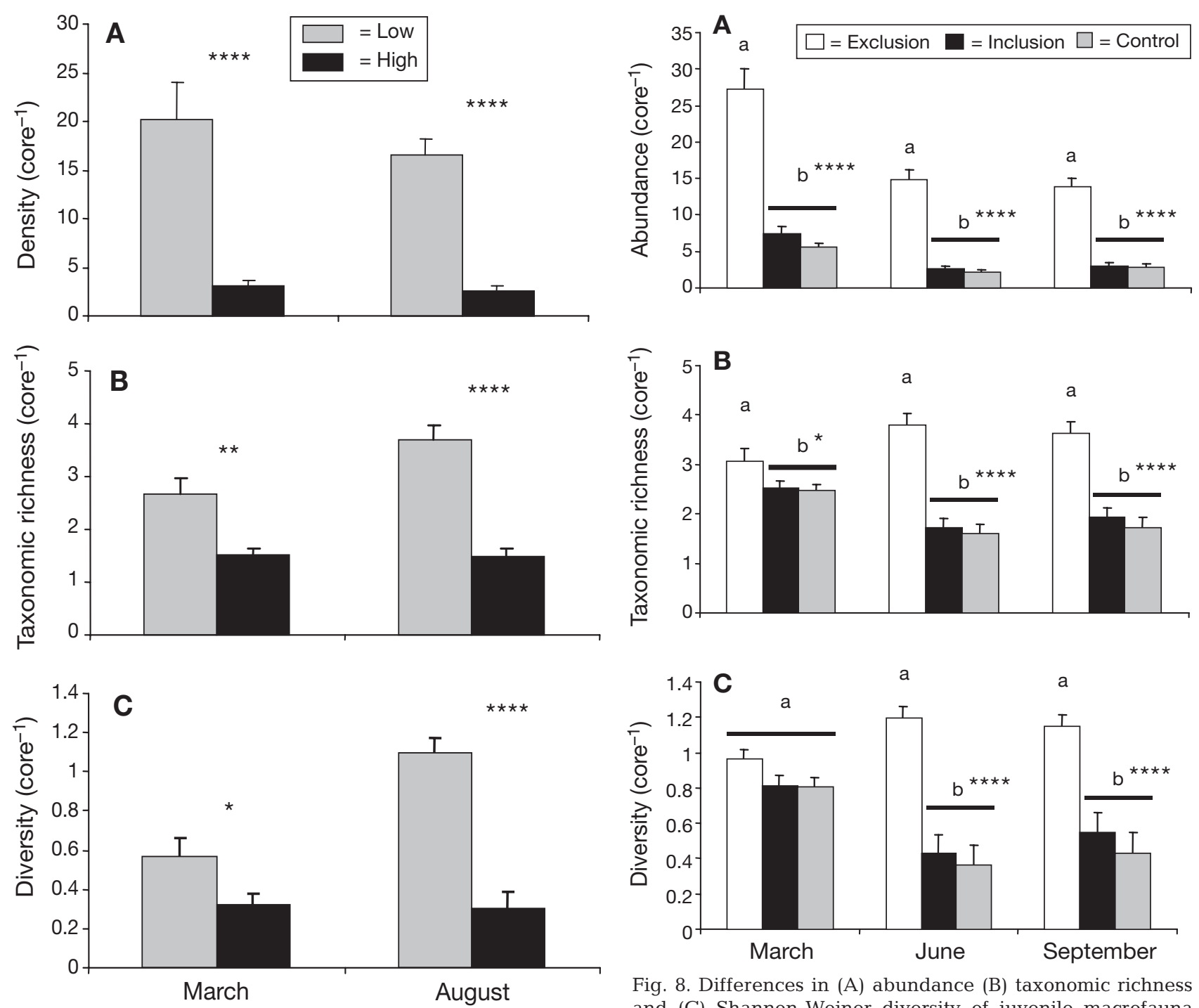

Fig. 7. Differences in (A) density, (B) richness (total number of taxa) and (C) Shannon-Wiener diversity of juveniles of macrofauna (mean $+1 \mathrm{SE}$ ) between areas of high and low Callianassa kraussi abundance in March and August. ${ }^{*} \mathrm{p}<0.05$, ${ }^{* *} \mathrm{p}<0.01,{ }^{* * * *} \mathrm{p}<0.0001 ; \mathrm{n}=9$ per site

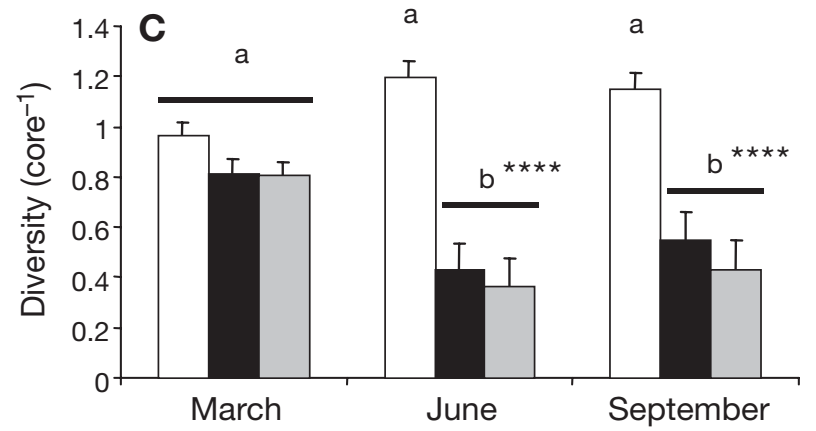

Fig. 8. Differences in (A) abundance (B) taxonomic richness and $(C)$ Shannon-Weiner diversity of juvenile macrofauna (mean $+1 \mathrm{SE}$ ) between exclusion, inclusion and control treatments in March, June and September. Different letters indicate statistical differences between treatments within any given month $\left({ }^{*} \mathrm{p}<0.05,{ }^{* * * *} \mathrm{p}<0.0001\right) ; \mathrm{n}=15$ per treatment per season

Whitney $U$-test, $\mathrm{p}<0.05$ for March, $\mathrm{p}<0.0001$ for August, Fig. 7) were consistently significantly greater in areas of low C. kraussi density than in high-density areas.

Similar trends were recorded in the manipulative experiment (Fig. 8). Total abundance, richness and diversity of recruits differed significantly among treatments, except in March, when diversity did not differ statistically among treatments. Apart from this exception, all 3 variables always had significantly greater values in exclusion than inclusion cages, and there were no significant differences between the controls and inclusion cages.

\section{Effects of biofilms on juvenile recruitment}

Concentrations of benthic microalgae and EPS were significantly reduced in the -biofilm treatment relative to the +biofilm treatment at Day 0 (Fig. 9), indicating that the use of UV lighting and autoclaving sediments had the desired effect of retarding biofilm development in the -biofilm treatment. Although the differences diminished over time, they remained very highly significant $(\mathrm{p}<0.0001)$ at all times.

The composition of the juvenile assemblage in the +biofilm treatment differed significantly from that of the -biofilm treatment (ANOSIM: Day 3, p = 0.002; 

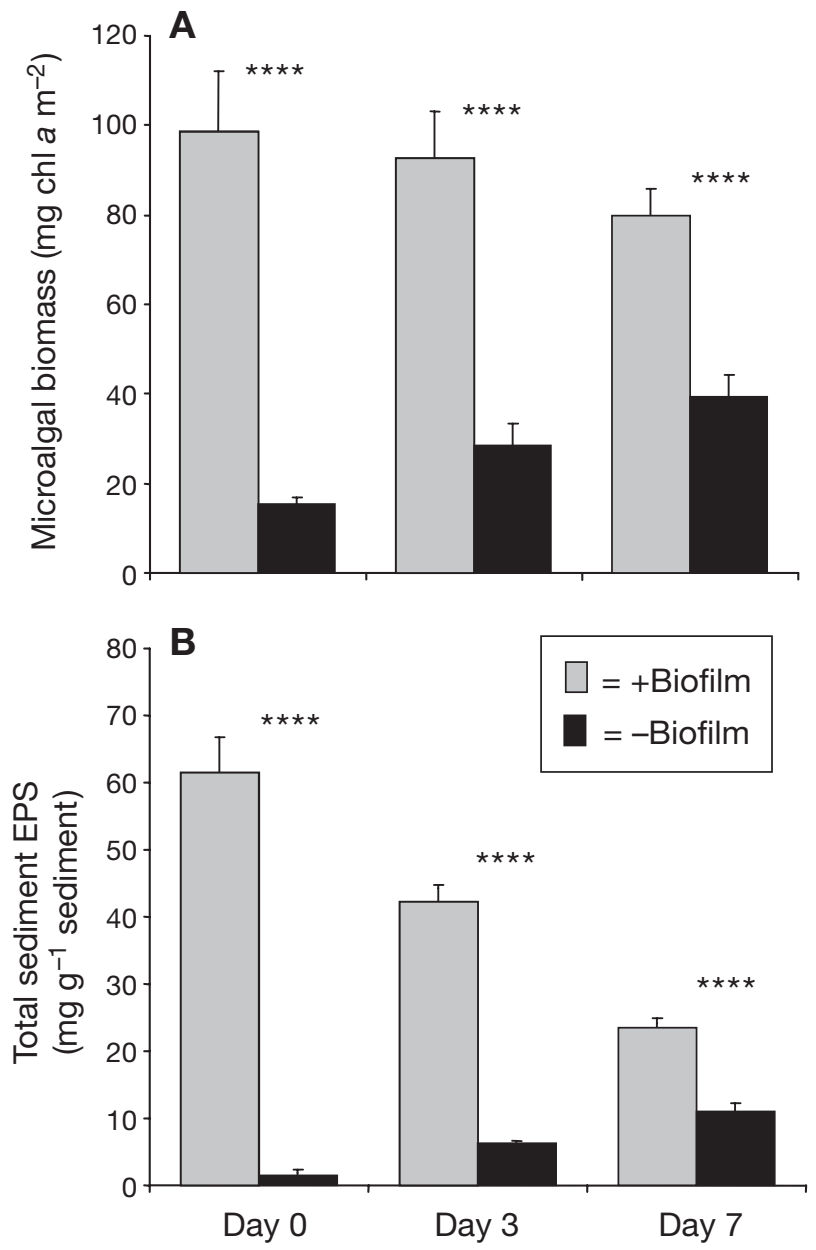

Fig. 9. Variations in (A) microalgal biomass and (B) total sediment EPS concentrations (mean $+1 \mathrm{SE}$ ) between the +biofilm and -biofilm treatments after Days 0, 3 and 7. ${ }^{* * *} \mathrm{p}<0.0001$; $\mathrm{n}=18$ per treatment per day
Day $7, p=0.009$ ). In biofilmed sediments the juvenile assemblages differed between 3 and $7 \mathrm{~d}$ samples $(\mathrm{p}=$ $0.017)$, but in non-biofilmed sediments they did not $(\mathrm{p}=0.106)$.

Different species changed in relative abundance over time. On Day 3, bivalves and the polychaetes Prionospio sexoculata and Desdemona ornata occurred in greater abundances in biofilmed sediments than non-biofilmed ones, and on Day 7, densities of bivalves, D. ornata $(\mathrm{p}<$ 0.001) and Cumacea were greater in biofilmed sediments. With the exception of capitellid polychaetes, the juveniles of all other taxa were more abundant in the +biofilm treatment than the-biofilm treatment (Fig. 10).

The abundance, species richness and diversity of recruits were roughly 2 to 4 times higher in biofilmed sediments than in non-biofilmed ones on both Days 3 and 7 (Fig. 11)

\section{DISCUSSION}

\section{Combining observational and experimental approaches}

The focus of the present study was to investigate the effects of Callianassa kraussi on sediment microbial biofilms and recruitment of juvenile macrofauna, relying both on a 'natural experiment' (in the form of comparative observations in different field situations) and on manipulative caging experiments. Combining the 2 approaches means that the problems associated with one are countered by the strength of the other.

The advantage of 'natural experiments' over manipulative caging experiments is that results are not
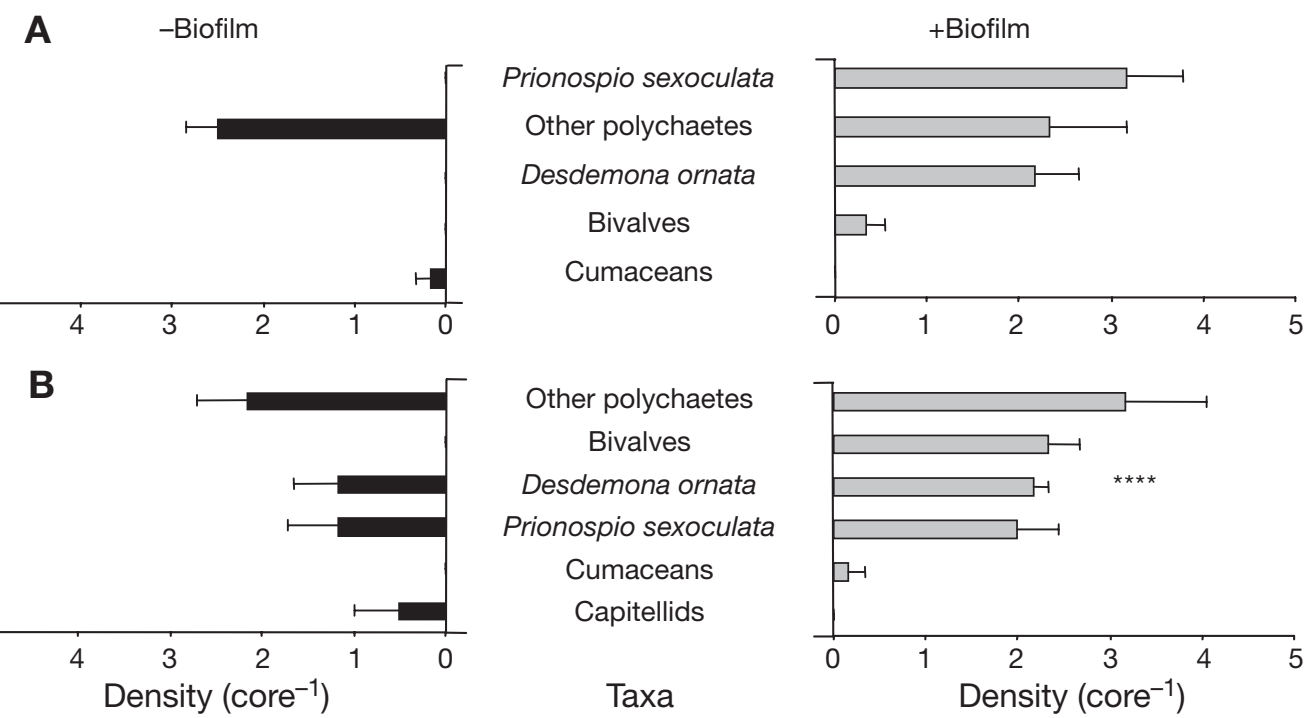

Fig. 10. Differences in abundance of juvenile macrofauna (mean $+1 \mathrm{SE}$ ) between the +biofilm and -biofilm treatments after (A) $3 \mathrm{~d}$ and (B) $7 \mathrm{~d}$ deployment in the field. ${ }^{* * * *} \mathrm{p}<0.0001 ; \mathrm{n}=6$ per treatment per day 

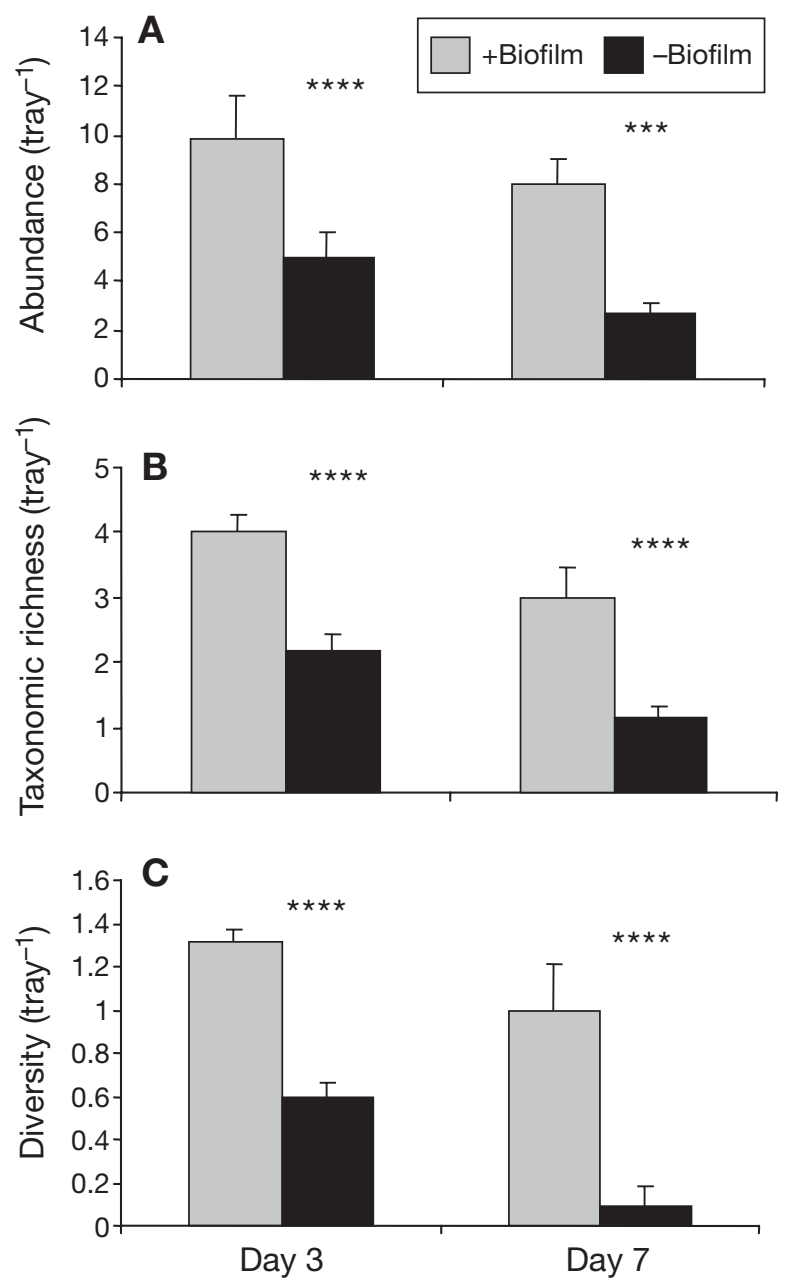

Fig. 11. Differences in (A) abundance, (B) taxonomic richness and $(C)$ Shannon-Weiner diversity of juvenile macrofauna (mean $+1 \mathrm{SE}$ ) between the +biofilm and -biofilm treatments after 3 and $7 \mathrm{~d}$ deployment in the field. ${ }^{* * *} \mathrm{p}<0.001$, ${ }^{* * * *} \mathrm{p}<0.0001 ; \mathrm{n}=6$ per treatment per day

influenced by experimental artifacts such as caging, which may confound the interpretation of results (Berkenbusch et al. 2000). However, results from natural experiments can easily be misinterpreted due to high levels of natural variability, or by failing to take into account the affects of factors outside those being investigated.

To counter this, we took measurements that demonstrated an absence of significant differences in physico-chemical conditions between sites with high and low densities of Callianassa kraussi. Moreover, correlation analyses virtually eliminated these physico-chemical factors as possible agents structuring juvenile assemblages. Other unmeasured factors may of course have played an undetected role. However, the density of $C$. kraussi and biofilm properties correlated strongly with juvenile communities, increasing confidence that differences in juvenile macrofauna and biofilms could be attributed to the effects of C. kraussi.

On the other hand, caging risks the introduction of artifacts into the experiment, which may alter patterns that would otherwise exist in the field. To overcome this, sediment cores taken from unmanipulated areas of high C. kraussi densities acted as a method control; any difference between biofilm properties or juvenile assemblages between controls and inclusion cages containing comparable densities of C. kraussi would have signaled cage-induced effects (Posey et al. 1991, Reinsel 2004).

In the caging experiment, the differences in biofilm properties and juvenile assemblages between the Callianassa kraussi inclusions and the controls were either small and marginally significant (in the case of microalgal biomass and EPS) or statistically non-significant (all other variables). The differences in microalgal biomass and EPS content that did exist between inclusion cages and control plots were small $(\sim 30 \%)$ compared to those between inclusion and exclusion treatments $(\sim 200 \%)$, indicating that any cage artifacts that did exist were minor. Moreover, if the cages were the cause of the differences in microalgal biomass and EPS, then one would have expected consistent effects on these 2 variables. This was, however, not the case: microalgal biomass was statistically less and EPS content greater in controls than in inclusion treatments.

There was no indication that the presence of experimental cages altered recruitment patterns of macrofauna. Diversity, richness and abundance of recruits never differed statistically between inclusion treatments and control plots during any sampling season. Additionally, the composition of juvenile assemblages associated with inclusion cages could not be statistically differentiated from that of control plots. Given these lines of evidence, we are confident that there were no important cage effects associated with the experimental protocol that might have confounded the interpretation of the results, and that the presence or absence of C. kraussi was the factor responsible for differences between inclusion and exclusion cages.

\section{Influence of Callianassa kraussi}

In both field observations and experiments, Callianassa kraussi clearly negatively affected the development of sediment microbial biofilms and the recruitment of juveniles of most macrofaunal taxa. Where $C$. kraussi was absent or scarce, the amounts of microalgae, bacteria and EPS and the densities of recruits were roughly 2 to 4 times greater than in areas with dense populations of C. kraussi. These trends were also mirrored by richness and diversity values, with almost 
twice as many juvenile taxa recorded with low densities of C. kraussi than when C. kraussi was abundant. The composition of juvenile assemblages occurring in areas where C. kraussi was naturally rare was also statistically different to those in dense $C$. kraussi beds. Parallel trends were recorded in the caging experiment. In particular, densities of juveniles of suspension-feeding taxa such as bivalves and the polychaete Desdemona ornata were greater in areas where C. kraussi was rare. Unidentified polychaetes, $D$. ornata and bivalves were also more abundant in the exclusion treatment compared to those in the inclusion treatment.

\section{Importance of biofilms}

The influences of Callianassa kraussi on juvenile stages were hypothesised to be mediated by its effects on microbial biofilms. When we manipulated biofilms, juvenile assemblages differed significantly between biofilmed and non-biofilmed sediments. Recruits were 2 to 3 times more abundant in biofilmed sediments than non-biofilmed ones. These trends were also reflected in species richness and diversity. Again, suspension-feeding taxa such as bivalves and the polychaete $D$. ornata and the subsurface-feeding polychaete Prionospio sexoculata were more abundant in biofilmed sediments.
As summarized in Fig. 12, there are 3 fundamental hypotheses that may explain the contrasting levels of biofilm development and the disparity in juvenile assemblages in areas of high versus low Callianassa kraussi densities or between inclusion and exclusion cages. The first is that $C$. kraussi turns over sediment at such a rate that larval settlers, bacteria and microalgae attempting to colonise the surface of these sediments may be buried by expelled sediments (Branch \& Pringle 1987), thereby losing contact with the water column and becoming smothered.

The second possibility is that sediments expelled by Callianassa kraussi are so erodable that bacteria, diatoms and larvae that try to colonise the sediment are swept away into the water column. The activities of deposit feeders have been shown to significantly increase the erodibility of sediments by disrupting natural sediment stabilizers such as diatoms and bacteria and the EPS they secrete (Widdows et al. 2000, de Deckere et al. 2001). Biofilms on sediments bind the topmost sediment layer and promote smooth laminar flow of water over the sediment bed (Paterson \& Hagerthey 2001). Where natural sediment stabilizers are reduced, as in heavily bioturbated habitats, the sediment bed resists water flow over it, and organisms that try to colonise these sediments are more prone to being swept into the water column (Paterson \& Hagerthey 2001).

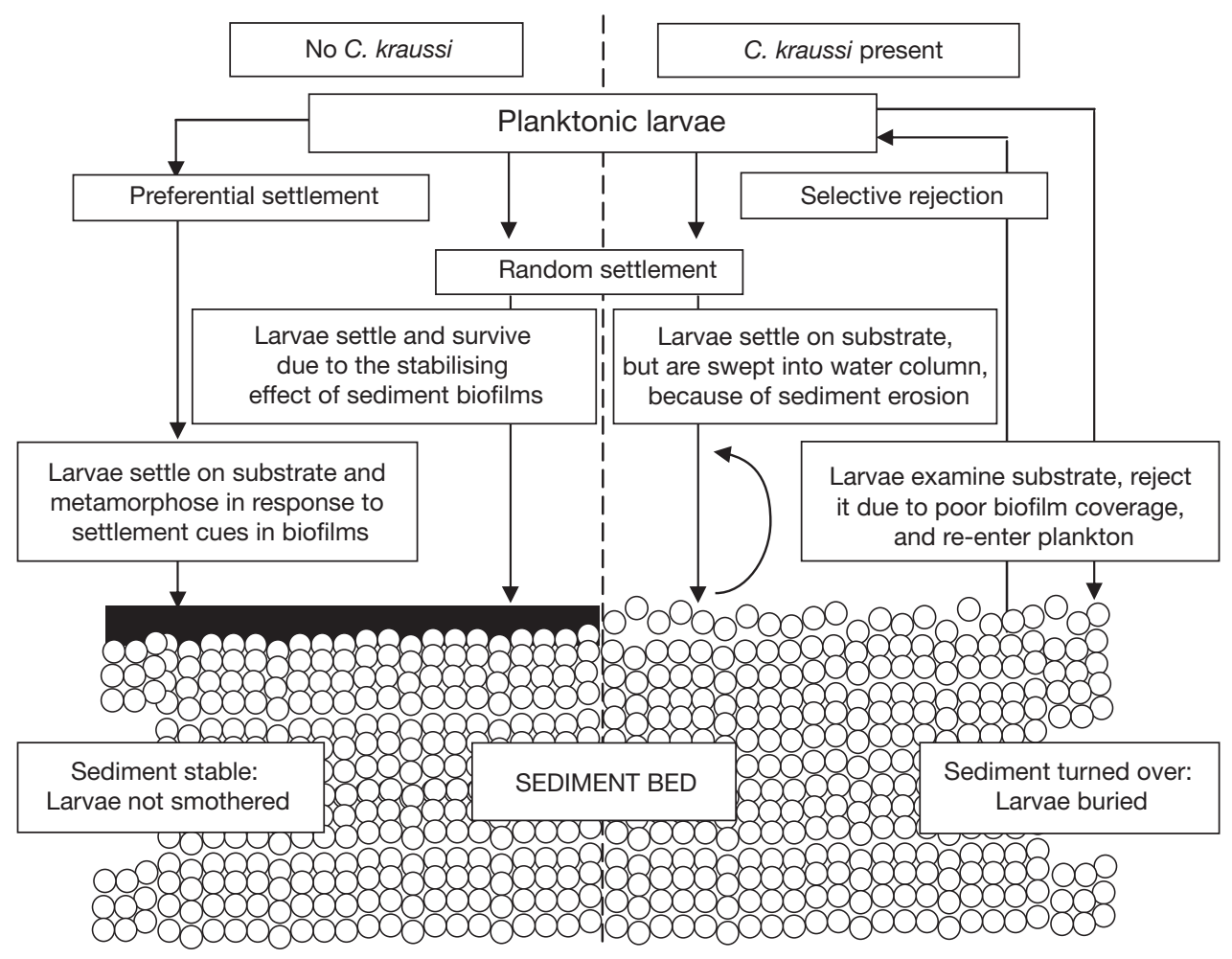

Fig. 12. Conceptual model highlighting the influence of sediment microbial biofilms in the recruitment of juvenile invertebrates 
The third possible mechanism for the disparity in juvenile macrofaunal assemblages between bioturbated and non-bioturbated areas is that larvae may settle preferentially at sites of low bioturbation intensities, using microbial biofilms as a settlement cue (Wilson 1955, Gray 1967, Pawlik 1992). When settling, macrobenthic larvae from the water column may explore the sediment surface and reject sediments bioturbated by C. kraussi, because they have poorly developed biofilms. The situation might be reversed in non-bioturbated sediments, where larvae may settle and metamorphose, because biofilm-derived settlement cues are detected.

This interpretation is supported by the work of Gray (1967), who showed that distribution of the polychaete Protodrilus rubropharyngeus on sandy beaches is a response to the localized presence of biofilms. Gray (1967) argued that these films act as settlement cues for larvae of this species. Preference experiments revealed that when natural sediments were treated with concentrated $\mathrm{H}_{2} \mathrm{SO}_{4}$, alcohol or formalin, or autoclaved to destroy biofilms, settlement of $P$. rubropharyngeus larvae was reduced. However, isolation of bacteria from natural sediment and inoculation onto 'unattractive' sediment restored larval settlement. Wilson (1955) and Meadows (1964) also showed that bacteria growing on sediments induce larval settlement of the polychaete Ophelia bicornis and of amphipods in the genus Corophium.

Under natural conditions, it is possible that the 3 hypotheses proposed above co-interact to shape juvenile assemblages. Although we have argued that Callianassa kraussi structures macrofauna by diminishing biofilms, thereby reducing settlement cues for larvae, it is additionally possible that the greater erodibility of non-biofilmed sediments may increase resuspension rates of newly settled larvae (Paterson \& Hagerthey 2001), or that sediments turned over by C. kraussi may bury larval settlers as proposed by Rhoads \& Young (1970). There is no way of distinguishing among these 3 mechanisms based on our data, but the following lines of reasoning are based on the idea that poorly developed biofilms act as a negative settlement cue. (1) For juveniles to recruit successfully, they must first settle and metamorphose. These processes are often triggered by preferred substrate-associated cues, which are usually biochemical in nature (Pawlik 1992, Eckman 1996), although other factors play a role, including physical characteristics and the presence or absence of conspecifics. (2) The most general largescale sediment-associated settlement cue planktonic larvae may encounter is microbial biofilms, which promote the settlement of a number of larval taxa (Gu et al. 1998, Hadfield \& Paul 2001, Huang \& Hadfield 2003). Once larvae settle and metamorphose, post- settlement factors such as larvae being buried by sediment turnover by C. kraussi or being washed into the water column due to the increased sediment erodibility may then become influential.

Therefore, the effect of C. kraussi on recruitment of macrofauna juveniles is most likely to operate through its effects on settlement, as this is the first step in the successful recruitment of juveniles. Well-developed biofilms associated with non-bioturbated sediments may act as positive settlement cues for larvae, while poorly developed biofilms may deter settlement. Whatever the precise mechanism, our data indicate that the presence of biofilms is causally linked to recruitment of juveniles, and our proposal is novel in suggesting that the influences of adult C. kraussi on macrofaunal assemblages include diminishment of recruitment because of the retardation of microbial biofilms.

Our investigations into the effects of Callianassa kraussi on juvenile macrofauna and the effects of biofilms on recruitment share striking similarities with results from an earlier investigation examining the effects on C. kraussi on adult macrofauna (Pillay et al. 2007b). Adult and juvenile assemblages differed significantly in the presence or absence of C. kraussi and in the parallel presence or absence of biofilms. Abundance, taxonomic richness and diversity of adult and juvenile assemblages also differed between treatments, with much of the dissimilarity between treatments attributed to the 'exclusion' of surfaceassociated organisms and suspension-feeding bivalves. Densities of adults and juveniles of sessile suspension feeders such as the polychaete Desdemona ornata, bivalves, and the sub-surface deposit-feeding polychaete Prionospio sexoculata were greater in cases where $C$. kraussi abundance was reduced. The effects of microbial biofilms on recruitment mirrored these trends, with the numbers of recruits of the above 3 taxa all being greater in biofilmed than nonbiofilmed sediments.

Suspension-feeding organisms have been shown to be susceptible to bioturbation because suspended sediments clog filtration apparatus and reduce filtration rates and body condition (Rhoads \& Young 1970, Pillay et al. 2007a). Rhoads \& Young (1970) have proposed that larvae of suspension feeders may be buried by sediment turned over by deposit feeders and used this as a mechanism to explain spatial separation between suspension feeders and deposit feeders. However, we propose that since the survival and body condition of suspension feeders are negatively affected by bioturbation (Pillay et al. 2007a), their larvae may selectively reject sediments bioturbated by sandprawns by using poorly developed biofilms as a negative settlement cue, as such behaviour would increase their subsequent survival and feeding chances. 
The similarity between the effects of Callianassa kraussi on juvenile and adult assemblages and the effects of natural biofilms on juvenile assemblages offers evidence that the patterns observed in macrofaunal assemblages are at least partly due to recruitment patterns dictated by the effects of $C$. kraussi on natural biofilms. This 'biofilm model' has not previously been used to explain how sandprawns influence the structure of macrofaunal communities, but our experiments indicate that it is an important process associated with bioturbation. As Eckman (1996) commented, we need to 'close the larval loop' and link larval and adult ecology to fully understand the population dynamics of marine benthic invertebrates.

Acknowledgements. This research was funded by the National Research Foundation of South Africa and the Andrew Mellon Foundation. We are grateful for the improvements made to the paper by anonymous reviewers.

\section{LITERATURE CITED}

Berkenbusch K, Rowden AA (2003) Ecosystem engineeringmoving away from 'just-so' stories. N Z J Ecol 27:67-73

Berkenbusch K, Rowden AA, Probert PK (2000) Temporal and spatial variation in macrofauna community composition imposed by ghost shrimp Callianassa filholi bioturbation. Mar Ecol Prog Ser 192:249-257

Branch GM (1984) Competition between marine organisms: ecological and evolutionary implications. Oceanogr Mar Biol Annu Rev 22:429-593

Branch GM, Pringle A (1987) The impact of the sand prawn Callianassa kraussi Stebbing on sediment turnover and on bacteria, meiofauna, and benthic microflora. J Exp Mar Biol Ecol 107:219-235

Brenchley GA (1981) Disturbance and community structure: an experimental study of bioturbation in marine softbottom environments. J Mar Res 39:767-790

Decho AW, Lopez GR (1993) Exopolymer microenvironments of microbial flora: multiple and interactive effects on trophic relationships. Limnol Oceanogr 38:1633-1645

de Deckere EMGT, Tolhurst TJ, Brouwer JFC (2001) Destabilization of cohesive intertidal sediments by infauna. Estuar Coast Shelf Sci 53:665-669

Dobretsov S, Qian PY (2006) Facilitation and inhibition of larval attachment of the bryozoan Bugula neritina in association with mono-species and multi-species biofilms. J Exp Mar Biol Ecol 333:263-274

Eckman JE (1996) Closing the larval loop: linking larval ecology to the population dynamics of marine benthic invertebrates. J Exp Mar Biol Ecol 200:207-237

Flach E, Tamaki A (2001) Competitive bioturbators on intertidal sandflats in the European Wadden Sea and Ariake Sound in Japan. In: Reise K (ed). Ecological comparisons of sedimentary shores. Ecological studies, Vol 151. SpringerVerlag, Berlin, p 149-168

Forbes AT (1973) A study of the burrowing sandprawn Callianassa kraussi Stebbing (Crustacea: Decapoda: Thalassinidea). PhD thesis, Rhodes University, Grahamstown

Gray JS (1967) Substrate selection by the archiannelid Protodrilus symbioticus. Helgol Wiss Meeresunters 46:253-269

Gu JD, Maki JS, Mitchell R (1998) Microbial biofilms and their role in the induction and inhibition of invertebrate settlement. In: D'Itri FM (ed) Zebra mussels and aquatic nuisance species. Ann Arbor Press, Ann Arbor, MI, p 343-357

Hadfield MG, Paul VJ (2001) Natural chemical cues for settlement and metamorphosis of marine-invertebrate larvae. In: McClintock JB, Baker BJ (eds) Marine chemical ecology. CRC Press, Boca Raton, FL, p 431-461

Huang S, Hadfield MG (2003) Composition and density of bacterial biofilms determine larval settlement of the polychaete Hydroides elegans. Mar Ecol Prog Ser 260:161-172

Lau SK, Thiyagarajan V, Qian PY (2003) The bioactivity of bacterial isolates in Hong Kong waters for the inhibition of barnacle (Balanus amphitrite Darwin) settlement. J Exp Mar Biol Ecol 282:43-60

Meadows PSM (1964) Experiments on substrate selection by Corophium species: films and bacteria on sand particles. J Exp Biol 41:499-512

Morgans JFC (1956) Notes on the analysis of shallow-water substrata. J Anim Ecol 25:367-387

Murphy RC, Kremer JN (1992) Benthic community metabolism and the role of deposit-feeding callianassid shrimp. J Mar Res 50:321-340

Olivier F, Desroy N, Retiere C (1996) Habitat selection and adult-recruit interactions in Pectinaria koreni (Malmgren) (Annelida: Polychaeta) post-larval populations: results of flume experiments. J Sea Res 36:217-226

Osman RW, Whitlatch RB (1995) The influence of resident adults on larval settlement: experiments with four species of ascidians. J Exp Mar Biol Ecol 190:199-220

Paterson DM, Hagerthey SE (2001) Microphytobenthos in contrasting coastal ecosystems: biology and dynamics. In: Reise K (ed) Ecological comparisons of sedimentary shores. Ecological studies, Vol 151. Springer-Verlag, Berlin, p 276-293

Pawlik JR (1992) Chemical ecology of the settlement of benthic marine invertebrates. Oceanogr Mar Biol Annu Rev 30:275-335

Pillay D (2006) The influence of bioturbation by the sandprawn Callianassa kraussi Stebbing on macrobenthic assemblages of the Little Lagoon. PhD thesis, University of KwaZulu-Natal, Durban

Pillay D, Branch GM, Forbes AT (2007a) The influence of bioturbation by the sandprawn Callianassa kraussi on feeding and survival of the bivalve Eumarcia paupercula and the gastropod Nassarius kraussianus. J Exp Mar Biol Ecol 344:1-9

Pillay D, Branch GM, Forbes AT (2007b) Experimental evidence for the effects of the thalassinidean sandprawn Callianassa kraussi on macrobenthic communities. Mar Biol 152:611-618 (doi: 10.1007/s00227-007-0715-z)

Posey MH, Dumbauld BR, Armstrong DA (1991) Effects of a burrowing mud shrimp, Upogebia pugettensis (Dana), on abundances of macro-infauna. J Exp Mar Biol Ecol 148: 283-294

Reinsel KA (2004) Impact of fiddler crab foraging and tidal inundation on an intertidal sandflat: season dependent effects in one tidal cycle. J Exp Mar Biol Ecol 313:1-17

Rhoads DC, Young DK (1970) The influence of depositfeeding organisms on sediment stability and community trophic structure. J Mar Res 28:150-178

Rowden AA, Jones MB (1993) Critical evaluation of sediment turnover estimates for Callianassidae (Decapoda: Thalassinidea). J Exp Mar Biol Ecol 173:265-272

Siebert T, Branch GM (2005) Interactions between Zostera capensis and Callianassa kraussi: influences on community composition of eelgrass beds and sandflats. Afr J Mar 
Sci 27:357-373

Siebert T, Branch GM (2006) Ecosystem engineers: interactions between eelgrass Zostera capensis and the sandprawn Callianassa kraussi and their indirect effects on the mudprawn Upogebia africana. J Exp Mar Biol Ecol 338: 253-270

Underwood GJC, Paterson DM (1995) The measurement of microbial carbohydrate exopolymers from intertidal sediments. Limnol Oceanogr 40:1243-1253

Waslenchuk DG, Matson EA, Zajak RN, Dobbs FC, Tramontano JM (1983) Geochemistry of burrow waters vented by a bioturbating shrimp in Bermudian sediments. Mar Biol $72: 219-225$

Widdicombe S, Austen MC, Kendall MA, Warwick RM, Jones MB (2000) Bioturbation as a mechanism for setting and maintaining levels of diversity in subtidal macrobenthic

Editorial responsibility: Howard Browman (Associate Editorin-Chief), Storebø, Norway communities. Hydrobiologia 440:369-377

Widdows J, Brinsley MD, Salkeld PN, Lucas CH (2000) Influences of biota on spatial and temporal variations in sediment erodibility and material flux on a tidal flat (Westerschelde, The Netherlands). Mar Ecol Prog Ser 194:23-37

Wieczorek SK, Todd CD (1998) Inhibition and facilitation of settlement of epifaunal marine invertebrate larvae by microbial biofilm cues. Biofouling 12:81-118

Wilson DP (1955) The role of micro-organisms in the settlement of Ophelia bicornis Savigny. J Mar Biol Assoc UK 34:531-543

Woodin SA (1976) Adult-Larval interactions in dense infaunal assemblages: patterns of abundance. J Mar Res 34:25-41

Woodin SA, Marinelli RL, Lindsay SM (1998) Process-specific cues for recruitment in sedimentary environments: geochemical signals? J Mar Res 56:535-558

Submitted: April 2, 2007; Accepted: May 14, 2007

Proofs received from author(s): September 12, 2007 